\title{
Kualitas Minuman Herbal Kulit Pisang Raja Bulu (Musa Paradisiaca L) pada Suhu Pengeringan Berbeda
}

\author{
HERLY DWI LESTARI ${ }^{1}$, SUKARSONO $^{1}$, ROIMIL LATIFA $^{1}$, HUSAMAH $^{1}$ \\ ${ }^{1}$ Pendidikan Biologi, Fakultas Keguruan dan Ilmu Pendidikan, Universitas Muhammadiyah Malang \\ Jl. Raya Tlogomas No. 246 Malang, Jawa Timur. \\ Email: herlydunkdunk@gmail.com
}

Received 6 October 2017; Received in revised form 17 January 2018; Accepted 2 February 2018; Available online 3 February 2018

\begin{abstract}
Banana peels have not been utilized optimally, just disposed of as organic waste or used as animal feed. Ripe banana peel skin is rich of chemical compounds which are antioxidants, both flavonoid compounds and other phenolic compounds. Banana peel contains high antioxidant activity compared to meat, especially "Raja Bulu" banana skin which has antioxidant equal to 97,85\%. Natural source of antioxidants in banana peel skin is very beneficial for health. The purpose of this study was to determine the effect of various drying temperature on antioxidant activity and the optimum drying temperature to antioxidant activity. This study also aims to determine the level of panelist's preference for herbal drinks of "Raja Bulu" banana peel with various drying temperatures. The type of research used is True Experimental Research. The study design was using RAL with 4 treatment $\mathrm{P}_{0}$ (control), $\mathrm{P}_{1}$ (drying temperature $75^{\circ} \mathrm{C}$ ), $\mathrm{P}_{2}$ (drying temperature $80^{\circ} \mathrm{C}$ ), $\mathrm{P}_{3}$ (drying temperature $85^{\circ} \mathrm{C}$ ). Data is included the amount of antioxidant activity content and the average of organoleptic properties of banana peel herbal drink. Data analysis techniques used are One Way Anova and qualitative descriptive. The results showed 1) Various drying temperature effect on the antioxidant activity of banana peel herbal drink. 2) The best treatment is $\mathrm{P}_{3}$ (drying temperature $85^{\circ} \mathrm{C}$ ) with antioxidant activity of $84,87 \%$. 3) The result of the panelist's favorite test for the best color, flavor and taste on $\mathrm{P}_{3}$ treatment with $85^{\circ} \mathrm{C}$ drying temperature.
\end{abstract}

Keywords: antioxidant activity, banana peel skin, herbal drink, organoleptic

\section{INTISARI}

Kulit buah pisang belum dimanfaatkan secara optimal, hanya menjadi limbah organik dan makanan ternak. Kulit pisang yang berwarna kuning kaya senyawa kimia antioksidan, baik flavonoid maupun fenolik. Kulit pisang mengandung aktivitas antioksidan tinggi dibandingkan dengan dagingnya, khususnya kulit pisang raja bulu yang memiliki antioksidan sebesar $97,85 \%$. Sumber antioksidan alami pada kulit pisang raja bulu sangat bermanfaat untuk kesehatan. Tujuan penelitian ini adalah untuk mengetahui pengaruh berbagai suhu pengeringan terhadap aktivitas antioksidan dan suhu pengeringan yang paling optimal terhadap aktivitas antioksidan. Penelitian ini juga bertujuan untuk mengetahui tingkat kesukaan panelis terhadap minuman herbal kulit pisang raja bulu dengan berbagai suhu pengeringan. Jenis penelitian yang digunakan adalah penelitian True Experimental. Rancangan penelitian menggunakan RAL dengan 4 perlakuan $\mathrm{P}_{0}$ (kontrol), $\mathrm{P}_{1}$ (suhu pengeringan $75^{\circ} \mathrm{C}$ ), $\mathrm{P}_{2}$ (suhu pengeringan $80^{\circ} \mathrm{C}$ ), $\mathrm{P}_{3}$ (suhu pengeringan $85^{\circ} \mathrm{C}$ ). Data berupa jumlah kandungan aktivitas antioksidan dan rerata sifat organoleptik minuman herbal kulit pisang raja bulu. Teknik analisis data yang digunakan adalah Anova One Way dan deksriptif kualitatif. Hasil penelitian menunjukkan 1) Berbagai suhu pengeringan berpengaruh terhadap aktivitas antioksidan minuman herbal kulit pisang raja bulu. 2) Perlakuan terbaik adalah $\mathrm{P}_{3}$ (suhu pengeringan $85^{\circ} \mathrm{C}$ ) dengan aktivitas antioksidan sebesar $84,87 \%$. 3) Hasil uji tingkat kesukaan panelis terhadap warna, aroma dan rasa terbaik pada perlakuan $\mathrm{P}_{3}$ dengan suhu pengeringan $85^{\circ} \mathrm{C}$. 
Kata Kunci: aktivitas antioksidan, kulit pisang, minuman herbal, organoleptik.

\section{PENDAHULUAN}

Pisang adalah tumbuhan monokotil yang termasuk dalam familia Musaceae yang berasal dari Asia Tenggara. Indonesia adalah negara penghasil buah pisang utama di Asia dengan jumlah produksi lebih dari 6 juta ton per tahun sehingga Indonesia ini merupakan negara penghasil buah pisang terbesar di Asia. Dilihat dari jumlah produksi pisang di Indonesia maka jumlah kulit pisang mencapai 2 juta ton per tahun. Pisang telah ditetapkan sebagai salah satu komoditas buah unggulan Nasional, salah satunya buah pisang raja bulu. Pisang ini merupakan jenis pisang yang paling banyak ditanam dan menjadi komoditas unggulan, karena disamping yang indah rasanya yang manis juga harga yang cukup tinggi di pasaran.

Pemanfaatan pisang raja bulu sebagai bahan industri salah satunya pembuatan Sale Pisang di kota Probolinggo Jawa Timur dalam pengolahannya hanya berhenti pada buah pisangnya saja, sedangkan kulit pisangnya dibuang sebagai limbah organik saja. Kulit pisang belum dimanfaatkan secara optimal, hanya dibuang sebagai limbah organik atau digunakan sebagai makanan ternak (Nuramanah, 2012). Kulit pisang raja bulu di Indonesia mencapai 3 juta per tahunnya. Kulit pisang masak yang berwarna kuning kaya akan senyawa kimia yang bersifat antioksidan, baik senyawa flavonoid maupun senyawa fenolik yang lainnya (Ernawati, 2016).

Alternatif memaksimalkan pengolahan limbah kulit pisang adalah dengan membuat produk bermanfaat (Dewatim 2008; Satria \& Ahda, 2009), salah satunya sebagai minuman herbal. Minuman herbal terkenal karena aroma, sifat antioksidan, dan aplikasinya pada bidang kesehatan. Pemberian zat antioksidan akan menghambat terjadinya proses oksidasi dalam tubuh dan mencegah stres oksidatif (Yanto et al., 2016).

Minuman herbal diolah dengan cara dikeringkan. Pengeringan minuman herbal ini mempunyai berbagai tujuan yaitu memperpanjang masa simpan, menghilangkan aktivitas enzim yang bisa menguraikan lebih lanjut zat aktif, memudahkan kita dalam pengelolaan selanjutnya dan dapat menguraikan senyawa racun pada bahan pangan (Harun, 2014). Jika suhu yang digunakan terlalu rendah maka kadar air yang terkandung di dalam bahan masih tinggi dan menyebabkan perkembangan mikroorganisme sehingga mudah terjadinya pembusukan, sementara kemampuan bahan untuk melepaskan air dari permukaannya akan semakin besar dengan meningkatnya suhu udara pengering yang digunakan sehingga kadar air yang dihasilkan akan semakin rendah (Fitriani, 2008). Namun apabila suhu yang digunakan terlalu tinggi tekstur bahan akan kurang baik serta merusak kandungan senyawa dari bahan tersebut. Kemampuan bertahan antioksidan terhadap proses pengolahan sangat diperlukan untuk dapat melindungi produk akhir (Widiastuti, 2013).

Kualitas minuman herbal ini diuji aktivitas antioksidan dan uji organoleptik agar masyarakat dapat mengonsumsi minuman sehingga kesehatan masih tetap terjaga tanpa mengganggu rutinitas. Antioksidan ini merupakan senyawa kimia yang dapat menyumbangkan satu atau lebih elektron kepada radikal bebas, sehingga radikal bebas tersebut dapat diredam. Antioksidan alami yang terdapat dalam kulit pisang raja bulu dapat melindungi tubuh terhadap kerusakan yang disebabkan spesies oksigen reaktif, mampu menghambat terjadinya penyakit degeneratif serta mampu menghambat peroksidase lipid pada makanan (Kuncahyo, 2007). Berdasarkan berbagai alasan tersebut, maka perlu dilakukan penelitian tentang kualitas minuman herbal kulit pisang raja bulu (Musa paradisiaca $\mathrm{L}$ ) pada suhu pengeringan berbeda.

Penelitian ini bertujuan untuk 1) menganalisis pengaruh berbagai suhu pengeringan terhadap aktivitas antioksidan minuman herbal kulit pisang raja bulu (Musa paradisiaca $\mathrm{L}$ ); 2) menganalisis berbagai suhu pengeringan yang berpengaruh paling optimal terhadap aktivitas antioksidan minuman herbal kulit pisang raja bulu (Musa paradisiaca L); 
dan 3) menganalisis organoleptik dilihat dari parameter warna, aroma dan rasa minuman herbal kulit pisang raja bulu (Musa paradisiaca L) pada suhu pengeringan berbeda.

\section{METODE}

Penelitian uji aktivitas antioksidan dilakukan di Laboratorium Kimia Universitas Muhammadiyah Malang. Jenis penelitian yang digunakan dalam penelitian ini adalah true eksperimental dengan design postest control group. Waktu penelitian dilaksanakan 12 Juni 2017- 30 Juni 2017. Rancangan penelitian yang digunakan adalah Rancangan Acak Lengkap (RAL). Rancangan ini merupakan rancangan yang perlakuannya diletakkan dan dilakukan secara acak pada setiap percobaan, hal ini berarti seluruh unit percobaan memiliki peluang yang sama untuk menerima perlakuan. Penelitian ini terdiri dari 4 varians perlakuan yaitu perlakuan berbagai suhu pengeringan $(\mathrm{P})$ yang terdiri dari $\mathrm{P}_{0}$ (tanpa adanya pengeringan), di oven suhu pengeringan $75^{\circ} \mathrm{C}$ $\left(\mathrm{P}_{1}\right)$, di oven suhu pengeringan $80^{\circ} \mathrm{C}\left(\mathrm{P}_{2}\right)$, di oven suhu pengeringan $85^{\circ} \mathrm{C}\left(\mathrm{P}_{3}\right)$. Setiap perlakuan dilakukan pengulangan sebanyak 6 kali.

Populasi dalam penelitian ini yaitu kulit pisang raja bulu yang telah matang sebanyak 5 $\mathrm{kg}$ dari home industri Sale Pisang Istimewa Kota Probolinggo. Sampel yang digunakan dalam penelitian ini yaitu sediaan kulit pisang raja bulu. Alat dan bahan yang digunakan yaitu Baskom, Pisau / cutter, Talenan, Timbangan, Oven, Plastik, Sealler, Kamera, Panci, Gelas ukur $100 \mathrm{ml}$ dan $200 \mathrm{ml}$, Pipet tetes, Pipet ukur, Labu takar $100 \mathrm{ml}$ dan $5 \mathrm{ml}$, Kuvet, Pengaduk kaca, Spektrofotometer, Sendok, Alat tulis, Kulit pisang raja bulu, Alumunium foil, Kertas label, Kantung teh, Air, Metanol, Aquades, DPPH, Tissue.

Proses pembuatan miniman herbal kulit pisang yaitu : 1) Pemisahan kulit pisang raja bulu dengan daging buah, 2) Cuci kulit pisang yang telah dipisahkan dari buah dengan air yang mengalir, 3) Merebus kulit pisang selama 20 menit untuk menghilangkan getah pada kulit pisang, 4) Mencuci kulit pisang yang telah direbus dengan air mengalir, 5) Setelah dicuci kulit pisang raja bulu diiris-iris menjadi potongan kecil-kecil 0,5 cm, 6) Memeras kulit pisang untuk menghilangkan getah yang masih menempel, 7) Meletakkan kedalam loyang kemudian di lakukan pengeringan dengan menggunakan oven selama 8 jam.

Teknik pengumpulan data yaitu uji aktivitas antioksidan menggunakan metode DPPH dan uji organoleptik dengan metode skoring di Labrotaroium Kimia UMM. Analisis data yaitu menggunakan One Way Anova dengan uji homegenitas dan uji BNT.

\section{HASIL}

Berdasarkan hasil penelitian uji aktivitas aktioksidan dan uji organoleptik yang dilakukan di Laboratorium Kimia Universitas Muhamamdiyah Malang tentang minuman herbal kulit pisang raja bulu dengan suhu pengeringan berbeda disajikan pada gambar 1 dan gambar 2, sebagai berikut:

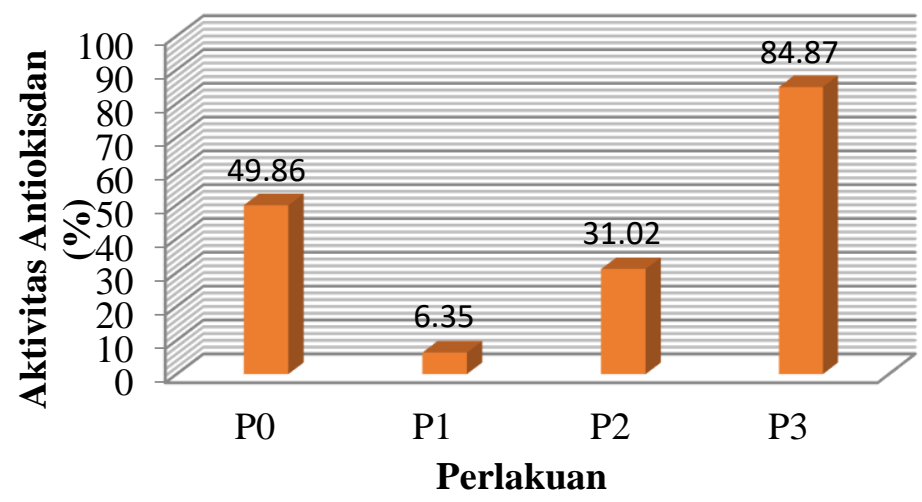

Gambar 1. Diagram batang rerata aktivitas antioksidan minuman herbal kulit pisang raja bulu (Musa paradisiaca L.) 


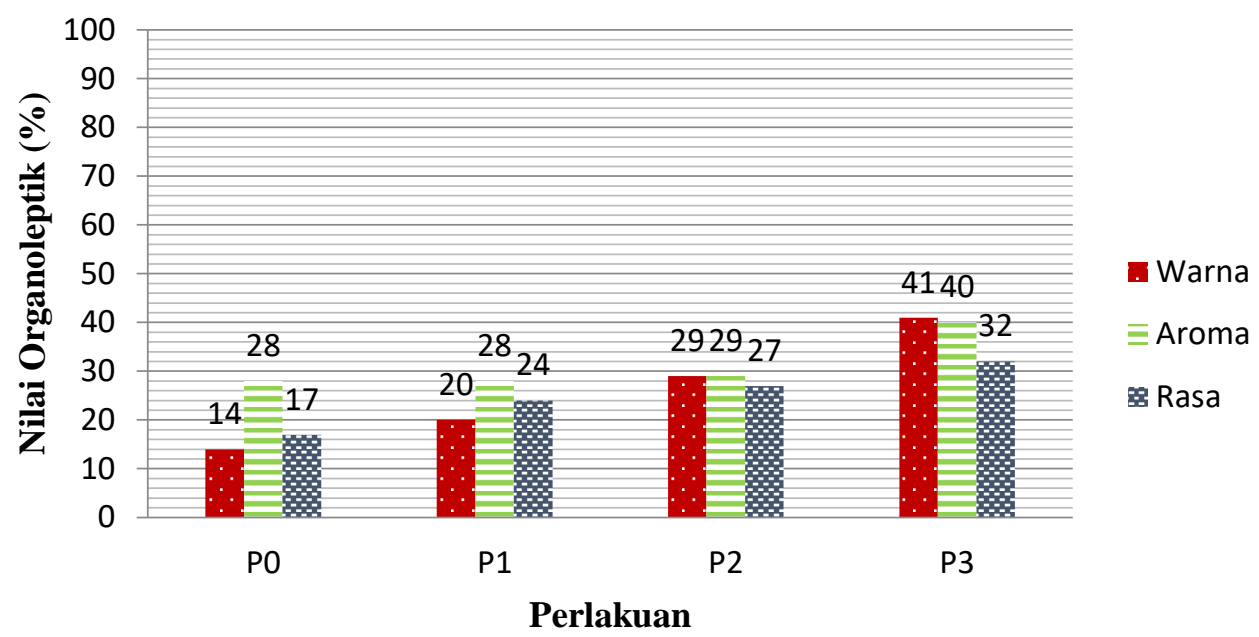

Gambar 2. Diagram Batang Rerata Jumlah Uji Organoleptik Warna, Rasa dan Aroma Minuman Herbal Kulit Pisang Raja Bulu

Gambar 1. menunjukkan bahwa pada tiaptiap perlakuan berbagai suhu pengeringan $(\mathrm{P})$ yang terdiri dari $\mathrm{P}_{0}$ (tanpa adanya pengeringan), di oven suhu pengeringan $75^{\circ} \mathrm{C}$ $\left(\mathrm{P}_{1}\right)$, di oven suhu pengeringan $80^{\circ} \mathrm{C}\left(\mathrm{P}_{2}\right)$, di oven suhu pengeringan $85^{\circ} \mathrm{C}\left(\mathrm{P}_{3}\right)$ didapatkan nilai aktivitas antioksidan yang bervariasi. Perlakuan yang memiliki nilai antioksidan dengan nilai tertinggi pada perlakuan $\mathrm{P}_{3}$ $(84,87 \%)$ dan nilai antioksidan terendah pada perlakuan P1 (6,35\%).

Gambar 2, secara deksriptif dapat dinyatakan bahwa (1) jika dibandingkan dengan perlakuan kontrol $\mathrm{P}_{0}$ (tanpa pengeringan) semua perlakuan memiliki rerata uji organoleptik warna yang lebih besar ; (2) jika dibandingkan dengan kelompok perlakuan, yang memiliki rerata hasil uji organoleptik warna tertinggi adalah perlakuan $\mathrm{P}_{3}$ dengan suhu pengeringan $85^{\circ} \mathrm{C}$; (3) jika dibandingkan dengan kelompok perlakuan, yang memiliki rerata hasil uji organoleptik warna terendah adalah perlakuan $\mathrm{P}_{1}$ dengan suhu pengeringan $75^{\circ} \mathrm{C}$.

\section{PEMBAHASAN}

Berdasarkan uji terencana BNT 5\% ke 4 (empat varians) perlakuan yaitu Perlakuan Kontrol tanpa pengeringan $\left(\mathrm{P}_{0}\right)$, perlakuan suhu pengeringan $75^{\circ} \mathrm{C}\left(\mathrm{P}_{1}\right)$, perlakuan suhu pengeringan $80^{\circ} \mathrm{C}\left(\mathrm{P}_{2}\right)$ dan perlakuan suhu pengeringan $85^{\circ} \mathrm{C}\left(\mathrm{P}_{3}\right)$ memilki perbedaan yang nyata. Hal ini di karenakan pada setiap perlakuan berbagai suhu pengeringan memilki kandungan yang tidak sama. Sehingga setiap kelompok varians memiliki kandungan antioksidan minuman herbal kulit pisang raja bulu (Musa paradisiaca L) yang berbeda.

Hasil uji terencana BNT 5\% ke 4 (empat) varians perlakuan memiliki kandungan antioksidan yang optimal yaitu pada perlakuan $\mathrm{P}_{3}$ (suhu pengeringan $85^{\circ} \mathrm{C}$ ) yaitu $84,87 \%$ dengan ditandai berkurangnya intensitas warna ungu larutan menjadi kuning. Adanya senyawa antioksidan menyebabkan perubahan warna violet menjadi kuning, karena semakin kuat senyawa antioksidan, makin jelas perubahan warna yang terjadi (Pisoschi, 2009). Faktor suhu memberikan pengaruh terhadap senyawa fenolik (Ningrum et al., 2016). Suhu yang terlalu lama akan mengakibatkan terjadinya pemaparan $\mathrm{O}_{2}$ semakin banyak, sementara terdapat beberapa komponen fenol yang bersifat termosensitif. Semakin tinggi suhu maka komponen polifenol yang larut akan semakin tinggi, tetapi pada suhu yang sangat tinggi akan menyebabkan senyawa polifenol rusak terdegradasi oleh panas (Nindyasari, 2012).

Oleh karena itu menurut Febrilani (2015) suhu harus dibatasi pada rentang $80-90^{\circ} \mathrm{C}$ agar tidak terjadi kerusakan senyawa polifenol. Menurut Nindyasari (2012) kadar flavonoid menurun sebesar $20 \%$ jika dipanaskan pada suhu diatas $98^{\circ} \mathrm{C}$ proses pemanasan dapat 
menyebabkan oksidasi dari komponen polifenol di dalam minuman herbal.

Antioksidan adalah molekul yang dapat menetralkan radikal bebas dengan cara menerima atau mendonorkan satu elektron untuk menghilangkan kondisi "elektron tidak berpasangan" (Muchtadi, 2013). Pada bahan pangan antioksidan banyak terdapat pada sayur-sayuran dan buah-buahan, yang salah satunya adalah pisang. Radikal bebas adalah sekelompok bahan kimia, berupa atom maupun molekul,yang kehilangan elektron sehingga molekul tersebut tidak stabil dan berusaha mengambil elektron dari molekul atau sel lain (Arief, 2006).

Metode DPPH (1,1-Diphenl-2pikrilhidrazil) terdiri dari tahapan pembuatan sampel terlebih dahulu. Menimbang bahan 2 gram, memasukkan ke dalam cangkir yang berukuran $75 \mathrm{ml}$. Mendidihkan air murni sampai pada $70^{\circ} \mathrm{C}$, kemudian menuangkan ke dalam cangkir yang telah berisi bahan, tutup dan membiarkan selama 6 menit, kemudian menyaringnya. Kemudian sebanyak $1 \mathrm{ml}$ seduhan teh dengan konsentrasi ditambahkan kedalam $2 \mathrm{ml}$ DPPH $0,1 \mathrm{mM}$. Campuran selanjutnya dikocok dan diinkubasi pada suhu kamar selama 30 menit ditempat gelap. Larutan ini selanjutnya diukur absorbansinya pada $\lambda$ maks $516 \mathrm{~nm}$. Perlakuan yang sama juga dilakukan untuk larutan blanko (larutan DPPH yang tidak mengandung bahan uji) Larutan blanko terdiri dari $2 \mathrm{ml}$ DPPH $0,1 \mathrm{mM}$ dan 1 ml metanol p.a (Sudaryat, 2015). Penggunaan metode DPPH (1,1-Diphenl-2-pikrilhidrazil) dalam penelitian ini disebabkan karena tahapan-tahapan yang dilakukan untukmengetahui aktivitas antioksidan dalam suatu bahan pada metode ini sangat mudah dan hanya membutuhkan waktu yang singkat.

Prinsip kerja dari metode ini adalah proses reduksi senyawa radikal bebas DPPH oleh antioksidan (Ananda, 2009). Proses reduksi ditandai dengan perubahan atau pemudaran warna larutan yaitu dari warna ungu pekat (senyawa radikal bebas) enjadi warna agak kekuningan (senyawa radikal bebas yang tereduksi oleh antioksidan).

Pada Gambar 2 menunjukkan warna seduhan tertinggi pada perlakuan $\mathrm{P}_{3}$ (suhu pengeringan $\left.85^{\circ} \mathrm{C}\right)$. Berdasarkan teori kulit pisang mengandung zat karoten (Nuramanah, 2012), pembuktian itu saya jelaskan pada seduhan minuman herbal kulit pisang raja bulu dengan perlakuan $\mathrm{P}_{3}$ (suhu pengeringan $85^{\circ}$ C). Semakin tinggi suhu pengeringan maka warna minuman herbal kulit pisang yang diperoleh semakin kuning, karena semakin banyak zat warna (karoten) yang keluar pada saat diseduh. Perbedaan warna pada masingmasing perlakuan disebabkan suhu pengeringan yang berbeda. Pengeringan menyebabkan perubahan seperti warna, rasa, dan aroma. Warna minuman herbal yang dihasilkan kuning, hal ini disebabkan zat karoten yang terkandung dalam kulit buah pisang. Berdasarkan SNI 3836-2013, warna minuman herbal 'teh' dalam kemasan yaitu warna khas. Warna digunakan sebagai parameter mutu dalam perdagangan (Harun, 2014).

Aroma minuman herbal kulit pisang raja bulu yang dihasilkan memiliki rata-rata aroma 28-40. Perlakuan yang memiliki rata-rata aroma 28-29 (beraroma agak harum kulit pisang) adalah perlakuan $\mathrm{P}_{0} \quad$ (tanpa pengeringan) $-\mathrm{P}_{2}$ (suhu pengeringan $80^{\circ} \mathrm{C}$ ) Perlakuan $\quad \mathrm{P}_{3}$ (suhu pengeringan $85^{\circ} \mathrm{C}$ ) memiliki rata-rata aroma 40 (beraroma harum). Semakin tinggi suhu yang digunakan maka jumlah air semakin menurun, sehingga aroma yang dihasilkan semakin khas. Perlakuan $\mathrm{P}_{3} \quad$ (suhu pengeringan $85^{\circ} \mathrm{C}$ ) memiliki rata-rata tertinggi yaitu 40 dan $\mathrm{P}_{1}$ (suhu pengeringan $75^{\circ} \mathrm{C}$ ) memiliki rata-rata terendah yaitu 28. Hal ini disebabkan pengeringan berfungsi untuk memperoleh aroma khas dari kulit pisang. Aroma khas yang dihasilkan dipengaruhi oleh komponen polifenol dalam seduhan kulit pisang akibat pemasakkan dengan pemanasan. Aroma akan timbul dan terasa lebih kuat sewaktu dilakukannya proses pemasakkannya seperti dipanggang, direbus ataupun digoreng.

Pada penelitian rasa minuman herbal kulit pisang raja bulu memiliki rata-rata 17-32. Pada perlakuan $\mathrm{P}_{0}$ (tanpa pengeringan) rata-rata yang dihasilkan 17 dan memiliki rasa sangat sepat. Rasa sepat pada minuman herbal kulit pisang raja bulu pada perlakuan $\mathrm{P}_{3}$ (suhu 
pengeringan $85^{\circ} \mathrm{C}$ ) tidak terlalu tajam dibandingkan $\mathrm{P}_{0}$ (tanpa pengeringan), $\mathrm{P}_{1}$ (suhu pengeringan $75^{\circ} \mathrm{C}$ ) dan $\mathrm{P}_{2}$ (suhu pengeringan $80^{\circ} \mathrm{C}$ ). Hal ini dikarenakan pemanasan dapat menurunkan kadar tanin, namun tidak dapat menghilangkan semua tanin sehingga masih meninggalkan rasa sepat (Gupita, 2012). Rasa sepat kurang disukai oleh sebagian panelis, namun beberapa panelis beranggapan minuman herbal sebagai jamu. Sehingga berdasarkan Gambar 2, perlakuan $\mathrm{P}_{3}$ menghasilkan rasa yang lebih dominan (disukai) karena rasa yang dihasilkan tidak terlalu sepat.

\section{KESIMPULAN}

Suhu pengeringan yang berbeda memberikan adanya pengaruh terhadap aktivitas antioksidan minuman herbal kulit pisang raja bulu (Musa paradisiaca L.) Suhu pengeringan yang paling optimal pada minuman herbal kulit pisang raja bulu (Musa paradisiaca) terhadap aktivitas antioksidan adalah pada perlakuan $\mathrm{P}_{3}$ (Suhu pengeringan $85^{\circ} \mathrm{C}$ ) dengan rerata $84,88 \%$.

Hasil uji organoleptik minuman herbal kulit pisang raja bulu (Musa paradisiaca $\mathrm{L}$ ) didapatkan hasil terbaik pada perlakuan $\mathrm{P}_{3}$ (suhu pengeringan $85^{\circ} \mathrm{C}$ ) dengan rerata warna 41 (kuning kemerahan), rata-rata aroma 40 (beraroma harum) dan rata-rata rasa 32 dengan rasa sepat yang tidak terlalu tajam.

\section{SARAN}

Berdasarkan hasil penelitian yang telah dilakukan perlu dilakukan penelitian lanjutan untuk meneliti cara menanggulangi rasa pahit pada minuman herbal kulit pisang raja bulu (Musa paradisiaca L).

\section{UCAPAN TERIMAKASIH}

Penulis menyampaikan terima kasih kepada Kepala dan tim peneliti Pusat Studi Lingkungan dan Kependudukan (PSLK) Universitas Muhammadiyah Malang yang telah memnberikan pendampingan dalam analisis dan memberikan inspirasi pengelolaan limbah pertanian.

\section{DAFTAR PUSTAKA}

Ananda AD. 2009. Aktivitas antioksidan dan karakteristik organoleptik minuman fungsional teh hijau (Camellia sinensis) rempah instan. Skripsi Tidak Di Publikasikan. Fakultas Pertanian IPB. Bogor.

Arief S. 2006. Radikal Bebas. Surabaya: Bagian/SMF Ilmu Kesehatan Anak FK UNAIR/RSU Dr. Soetomo.

Dewati R. 2008. Limbah Kulit Pisang Kepok Sebagai Bahan Baku Pembuatan Ethanol. Surabaya: UPN Veteran Jatim Press.

Ernawati WO, Wahyuni S, Rejeki S. 2016. Kajian Pemanfaatan Limbah Kulit Pisang Raja (Musa paradisiaca var Raja) Dalam Pembuatan Es Krim. Jurnal Sains dan Teknologi Pangan. 1(1): 67-72.

Febrilani RD. 2015. Kajian Berat Daun Salak Kering Dan Suhu Awal Air Penyeduh Terhadap Aktivitas Antioksidan Air Seduhan Teh Herbal Daun Salak Bongkok (Salacca edulis Reinw). [Thesis]. Bandung: Universitas Pasundan.

Fitriani S. 2008. Pengaruh suhu dan lama pengeringan terhadap beberapa mutu manisan belimbing wuluh (Averrhoa bellimbi L.). Sagu. 7(1): $32-37$.

Gupita C dan Rahayuni A. 2012. Pengaruh Berbagai Ph Sari Buah Dan Suhu Pasteurisasi Terhadap Aktivitas Antioksidan Dan Tingkat Penerimaan Sari Kulit Buah Manggis. [Thesis]. Semarang: Universitas Diponegoro.

Harun H, Efendi R, Simanjuntak L. 2014. Penerimaan Panelis Terhadap Teh Herbal Dari Kulit Buah manggis (Garcinia mangostana L.) Dengan Perlakuan Suhu Pengeringan. Sagu. 13(2): 7-18.

Kuncahyo I dan Sunardi. 2007. Uji Aktivitas Antioksidan Ekstrak Blimbing Wuluh (Averrhoa blimbi L.) Terhadap 1,1diphenyl-2-picrylhidrazil (DPPH). Prosiding Seminar Nasional Teknologi. 24 November 2007. Yogyakarta: ISSN 1978-9997. hal 1-9

Muchtadi D. (2013). Antioksidan dan Kiat Sehat di Usia Produktif. Bandung: Alfabeta.

Nindyasari S. 2012. Pengaruh Suhu Dan Waktu Penyeduhan Teh HijaU (Camellia 
sinensis) Serta Proses Pencernaan in Vitro Terhadap Aktivitas Inhibisi Lipase. Skripsi Tidak Di Publikasikan. Fakultas Teknologi Pertanian. Institut Pertanian Bogor.

Ningrum R, Purwanti E, Sukarsono. 2016. Alkaloid Compound Identification of Rhodomyrtus tomentosa Stem as Biology Instructional Material for Senior High School X Grade. Jurnal Pendidikan Biologi Indonesia, 2(3): 231-236.

Nuramanah E, Sholihin H, Siswaningsih W. 2012. Kajian Aktivitas Antioksidan Kulit Pisang Raja Bulu (Musa paradisiaca L. var sapientum) dan Produk Olahannya. Jurnal Sains dan Teknologi Kimia, 4(1): 1-7.

Pisoschi AM, Cheregi MC, Danet AF. 2009. Total Antioxidant Capacity of Some Commercial Frui Juices: Electrochemical and Spectrophotometrical Approaches, Molecules $\quad 14: \quad 480-493$. doi:10.3390/molecules140104.
Satria BH dan Ahda Y. 2009. Pengolahan Limbah Kulit Pisang Menjadi Pektin Dengan Metode Ekstraksi. Online: eprints.undip.ac.id/3671/1/MAKALAH_Y usuf_Ahda.pdf

Sudaryat Y, Kusmiyati, Mimin, Pelangi CR., Rustamsyah A, Rohdiana D. 2015. Aktivitas antioksidan seduhan sepuluh jenis mutu teh hitam (Camellia sinensis L. O. Kuntze) Indonesia. Jurnal Penelitian Teh dan Kina, 18(2): 95-100.

Widiastuti, Fitriani S, Ali A. 2013. Pengaruh Suhu Dan Lama Pengeringan Terhadap Mutu Manisan Kering Jahe (Zingiber Officinale Rosc.) Dan Kandungan Antioksidannya. SAGU, 12(2): 1-8.

Yanto AR, Mahmudati N dan Susetyarini RE. 2016. Steeping of Ginger (Zingiber officinale Rosce) Lowers Blood Glucose in Rat Model Type-2 Diabetes (NIDDM) as a Learning Resource Biology. Jurnal Pendidikan Biologi Indonesia, 2(3): 258264. 